\title{
Lack of genetic structure in greylag goose (Anser anser) populations along the European Atlantic flyway
}

Irene Pellegrino, Marco Cucco, Arne Follestad, Mathieu Boos

Greylag goose populations are steadily increasing in north-western Europe. Although individuals breeding in the Netherlands have been considered mainly sedentary birds, those from Scandinavia or northern Germany fly towards their winter quarters, namely over France as far as Spain. This study aimed to determine the genetic structure of these birds, and to evaluate how goose populations mix. We used mitochondrial DNA and microsatellites from individuals distributed throughout the European Atlantic flyway, from breeding sites in Norway and the Netherlands to stopover and wintering sites in northern and south-western France. The mtDNA marker (CR1 D-Loop, 288 bp sequence, 151 ind.) showed 24 different haplotypes. The genetic distances amongst individuals sampled in Norway, northern France and the Netherlands were low (range 0.012-0.013). Individuals in south-western France showed a slightly higher genetic distance compared to all other sampling areas (ranges 0.016-0.017). The NJ tree does not show evidence of any single clades grouping together all individuals from the same geographic area. Besides, individuals from each site are found in different branches. Bayesian clustering procedures on 14 microsatellites (169 individuals) did not detect any geographically distinct cluster, and a high genetic admixture was recorded in all studied areas except for the individuals from the breeding sites in Norway, which were genetically very close. Estimation of migration rates through Bayesian inference confirms the scenario for the current mixing of goose populations. 


\section{Lack of genetic structure in greylag goose (Anser anser) populations along the} 2 European Atlantic flyway

4 Irene Pellegrino, University of Piemonte Orientale, DISIT, Alessandria, Italy. Email: irene.pellegrino@unipmn.it

6 Marco Cucco, University of Piemonte Orientale, DISIT, Alessandria, Italy.Email: cucco@unipmn.it

7 Arne Follestad, Norsk Institutt for Naturfoskning Postboks 5685 Sluppen, 7485 Trondheim, Norway. Email:arne.follestad@nina.no

9 Mathieu Boos, Naturaconst@, Research Agency in Applied Ecology, 67270 Wilshausen, France. Email: mboos.naturaconst@free.fr

12 Corresponding author

13 Marco Cucco, University of Piemonte Orientale, DISIT, viale Michel 11, 15121 Alessandria, Italy. Tel. +30.0131360276,Email:cucco@unipmn.it 
Introduction

18 The greylag goose (Anser anser) is widespread throughout the Palearctic. In Europe, the main breeding

19 populations are located in central and northern countries, and the species rarely breeds in Mediterranean areas (Cramp, 1977; Hagemeijer \& Blair, 1997; BirdLife International, 2004). European populations show different patterns of movement. Although individuals breeding in Scotland and the Netherlands are considered sedentary birds (Delany \& Scott, 2006), those from Scandinavia or central Europe fly longer distances, namely over France to Spain, with some individuals reaching north Africa (Fox et al., 2010; Nilsson et al., 2013). Icelandic breeders winter in Ireland and Britain, and greylags from Russia reach the regions bordering the eastern Mediterranean, Black and Caspian seas. Individuals with morphological characters ascribed to the oriental subspecies rubrirostris have been observed on rare occasions in western Europe (Cramp, 1977).

Widescale movement patterns have been studied through the recapture or resighting of marked birds (coloured neck collars and leg rings, see Nilsson et al., 2013). These methods gave valuable information about the origin of birds that were found in moulting areas (Nilsson, Kahlert \& Persson, 31 2001), flying, or staging in winter quarters. Birds from Sweden and Norway fly to Denmark and/or the 32 Netherlands (SOVON, 1987; Persson, 1993; Andersson et al., 2001). Recent monitoring of greylags tagged with GPS devices in Norway show that approximately $30-50 \%$ can stay in the Netherlands during the whole wintering season, whereas others migrate to France or Spain. These geese all return to their previous breeding sites, thus showing a high breeding site fidelity (Boos et al., 2012, Boos unpublished data). According to Ramo et al. (2012), an increasing number of greylag geese winter at higher latitude. A noticeable effect of climatic changes probably explains this increasing tendency for geese to winter more 38 closely to their breeding grounds.

40 Portugal, with arrivals from Scandinavia, Poland, Denmark and Germany (Fouquet et al., 2009). The 41 situation in France is particularly complicated, because noticeable fluxes of geese coming from northern 
42 or Central Europe are found not only along the Atlantic flyway but also in other areas located in central

43 and south-eastern France. The departure areas of these birds have yet to be been fully determined, and the

44 timing of migration can probably differ depending on the origin of the populations (Fouquet, 1991;

45 Comolet-Tirman, 2009). Furthermore, the relative proportion of geese travelling to France and originating

46 from different countries may change over time (Pistorius, Follestad \& Taylor, 2006; Pistorius et al.,

47 2007). However, data from neck-collared or ringed geese can be skewed by variations in the marking and

48 resighting efforts of the countries involved (Nilsson, 2007; Nilsson et al., 2013), and this makes it

49 difficult to fully define the composition of goose subpopulations migrating south from observational data

50 alone.

51 Genetics have become a useful tool in the study of migration and wintering patterns. Recent

52 studies on Anseriforms examined spatial structure along the flyways or in wintering zones, then compared

53 it to genetic data in breeding areas. In the king eider (Somateria spectabilis), strong site fidelity to

54 wintering areas and pair formation at wintering quarters indicated a population structure defined by

55 wintering rather than nest-site philopatry (Pearce et al., 2004). However, genetic analyses of mtDNA and

56 microsatellite alleles showed a lack of spatial genetic structure, suggesting the possible existence of flows

57 with homogenized gene frequencies. In the mallard (Anas platyrhynchos), single nucleotide markers were

58 used to investigate population structure on a continental scale throughout the northern hemisphere. This

59 genetic analysis found a general panmixia, suggesting that mallards form a single large, interbreeding

60 population (Kraus et al., 2013). The tufted duck (Aythya fuligula) shows high breeding site fidelity, but

61 mtDNA and microsatellite markers revealed an extensive population admixture on the wintering ground

62 (Liu et al., 2012, 2013). In the common pochard (Aythya ferina), genetic differentiation was observed

63 among Eurasian breeding populations, but no evidence of genetic structure was detected for pochards

64 sampled on European wintering grounds (Liu, Keller \& Heckel, 2011).

65 Relatively few studies have investigated the genetic aspects of European geese of the genus

66 Anser, and the subject has not been thoroughly investigated at all in the greylag goose. Studies by

67 Ruokonen $(2004,2005)$ examined the genetic variability in two species of conservation concern, the 
68 lesser white-fronted goose (Anser erythropus) and the pink-footed goose (Anser brachyrhynchus), and

69 investigated the phylogenetic relationship between seven Anser species (Ruokonen, Kvist \& Lumme,

70 2000). A small amount of genetic differentiation between species has been observed in this genus

71 (Ruokonen, Kvist \& Lumme, 2000; Johnsen et al., 2010).Actually, mitochondrial DNA showed the

72 presence of highly fragmented populations in two species of conservation concern, the lesser white-

73 fronted goose (Anser erythropus, Ruokonen et al., 2004) and the pink-footed goose (Anser

74 brachyrhynchus, Ruokonen, Aarvak \& Madsen, 2005).

75 However, population genetics among species of geese has not been investigated to date. Here we used both mitochondrial DNA and microsatellites to study the characteristics of greylag geese from two

77 breeding areas (the Netherlands and north-western Norway) and two wintering zones (northern France 78 and south-western France). This study investigates to what extent populations are genetically 79 differentiated. Genetic structure could have been increased by the fragmentation of breeding geese in 80 separated areas, or on the contrary, a limited genetic structure could have been developed by i) the widespread practice of amateur breeding and selling of geese (Hagemeijer \& Blair, 1997; Wang et al.,

82 2010), ii) the recent increase in the size of several populations (Klok et al., 2010), and iii) the habit of 83 European geese to rest several times during their flight toward their winter quarters (Fouquet, Schricke \& 84 Fouque, 2009) at stopover sites where individuals from distant areas can admix and form pair bonds. Knowledge of the genetic structure and diversity of greylag goose populations is a necessary scientific basis to manage this emblematic species (Lorenz, 1966) and decide on appropriate action for its conservation (Kampe-Persson, 2002) in the light of serious recent conflicts with agricultural and habitat protection interests in most north European countries (Klok et al., 2010).

91 Methods

92

\section{Sample collection and DNA extraction}


94 We analyzed feather samples from 174 greylag geese (Appendix 1) collected over the European Atlantic

95 flyway (from two breeding grounds: in north and western Norway, and six staging grounds: in the

96 Netherlands, northern France and south-western France; see Table 1 and Fig. 1). One additional

97 individual was collected in the Republic of Kalmykia in an area associated with the eastern rubrirostris

98 subspecies (Cramp, 1977). During the 2010/2011 and 2011/2012 (including 1-10 February) wintering

99 seasons in France, goose feathers were obtained from greylag geese collected during the legal hunting

100 period in natural areas by hunters collaborating with the study. Samples from the Netherlands were

101 obtained on wild free-ranging geese collected in natural areas in the Zeeland region (near Rilland) by a

102 local hunter before the $20^{\text {th }}$ of September in 2011 and 2013, i.e. before the arrival of geese breeding in

103 Norway or in Sweden (Nilsson, 2006, 2007; Boos pers. obs. based on GPS data). Samples from Norway

104 were obtained from birds that were collected during the spring and summer legal hunting seasons, or from

105 geese that were caught during the moulting period in 2010 and 2011 by A.F. for the Nordic Greylag

106 Goose Project, which studies the ecology of the Norwegian breeding goose population (Nilsson, 2007).

107 Feather calami were stored in ethanol at $-20^{\circ} \mathrm{C}$, and total DNA was extracted using the commercial

108 NucleoSpin®Tissue kit (Macherey-Nagel, Düren, Germany). After extraction, genomic DNA was 109 stocked at $-20^{\circ} \mathrm{C}$.

\section{Mitochondrial DNA sequencing}

112 Partial mitochondrial control region (CR1 D-Loop 288 bp) was amplified in 144 of the 174 individuals

113 (Appendix 1) using L180 (5'TGgtTAtgCATAtTCGTGCATAGA'3) and H466

114 (5'TtTCACGTGAgGagtaCGACTAAT'3) primers (Ruokonen et al., 2000). PCR amplifications were carried

115 out in a Bio-Rad thermal cycler (Bio-Rad Laboratories Inc.; Hercules, California, USA). PCR reaction

116 was performed in a final volume of $25 \mu$ containing $0.4 \mu \mathrm{dNTPs}(10 \mathrm{mM}), 1 \mu 1 \mathrm{MgCl}_{2}(25 \mathrm{mM}), 0.3 \mu 1$

117 of each primer ( $25 \mathrm{pmol} / \mu \mathrm{l}), 2.5 \mu \mathrm{l} 10 \times$ buffer, $0.4 \mu \mathrm{l}$ Taq polymerase ( 5 unit/ $\mu \mathrm{l}$; QIAGEN), ddH2O and

118 genomic DNA (20-100 $\mathrm{ng} / \mu \mathrm{l})$. The selected cycling profile included a $4 \mathrm{~min}$ preliminary denaturation

119 cycle at $94{ }^{\circ} \mathrm{C}$ followed by 32 denaturation, annealing and extension cycles $\left(30 \mathrm{~s}\right.$ at $94{ }^{\circ} \mathrm{C}, 30 \mathrm{~s}$ at $58{ }^{\circ} \mathrm{C}$ 
120 and $30 \mathrm{~s}$ at $72{ }^{\circ} \mathrm{C}$, respectively) before a final extension of $7 \mathrm{~min}$. Negative controls were included for 121 amplification procedures to detect contaminations.

122 The PCR product was purified using the EXO-SAP procedure with Exonuclease I (Exo;

123 Fermentas, Burlington, Canada) and Shrimp Alkaline Phosphatase (SAP; Fermentas, Burlington,

124 Canada). The purification cycle consisted of $30 \mathrm{~min}$ at $37{ }^{\circ} \mathrm{C}$, then $15 \mathrm{~min}$ at $80^{\circ} \mathrm{C}$ to deactivate the 125 enzymes followed by a 10 min cooling-down step at $4{ }^{\circ} \mathrm{C}$. DNA concentration was determined after 126 electrophoresis in $1.8 \%$ agarose gels (TBE 1\%) stained with ethidium bromide and visualized in a UV127 trans illuminator Gel Doc XR (Bio-Rad Laboratories Inc.; Hercules, California, USA) using the 128 Molecular Imager ChemiDoc XRS System and Quantity One software (Bio-Rad Laboratories Inc.; 129 Hercules, California, USA).

130 Sequencing was carried out at Macrogen Laboratories (Amsterdam, The Netherlands) in an ABI 131 3730xl Analyzer (Applied Biosystems).

132 Raw electropherograms were checked visually using FINCHTV (Geospiza Inc.; Seattle, WA,

133 USA; http://www.geospiza.com), and sequences were aligned with ClustalW algorithm in BIOEDIT 7.05

134 (Hall, 1999). The haplotype network was calculated in Network 4.6 (Fluxus Technology Ltd; Clare,

135 Suffolk, England; fluxus-engineering.com) using the median joining procedure (MJ: Bandelt et al., 1999).

136 DNASP version 5 (Librado \& Rozas, 2009) was used to estimate mtDNA haplotype diversity (h),

137 nucleotide diversity $(\pi)$ and the mean number of pairwise differences $(k)$ in the sampled areas.

138 Demographic and/or spatial population expansion events were investigated using the mismatch

139 distribution implemented in DNASP v. 5. MEGA 5.0 (Tamura et al., 2011) was used to perform the

140 neighbour-joining method (NJ: Saitou and Nei, 1987), clustering pairwise Tamura-Nei’s genetic distances

141 between haplotypes (TN93: Tamura and Nei, 1993). Support for the internodes in the NJ tree was

142 assessed by bootstrap percentages (BP: Felsenstein, 1988) after 1000 resampling steps. One sequence of

143 Anser anser anser (GenBank AF159962) from Finland and another of Anser anser rubrirostris (GenBank

144 AF159963) from Slimbridge Wetland Center, England, were included as reference sequences in tree 
145 construction. A sequence of the lesser white-fronted goose (Anser erythropus, GenBank AY072580) and 146 the bean goose (Anser fabalis, GenBank AB551534) were used as outgroups.

147 Maximum likelihood (ML) and maximum parsimony (MP) trees were obtained through the 148 DNAML, CONSENSE, DNAPARS programmes in PHYLIP 3.67 (Felsenstein, 2005). Bootstrap values

149 were based on 1000 replicates, and the tree topologies were visualized with FIGTREE 1.3.1 (Rambaut, 150 2008). The best substitution model for molecular evolution was selected using the corrected Akaike

151 Information Criterion (AICc, Burnham and Anderson, 2004) in JMODELTEST (Posada, 2008). Maximum

152 likelihood bootstrap supports were estimated by performing 100 runs with 1000 bootstrap replicates.

153 The partition of mtDNA diversity within and among the sampled geographical populations were

154 investigated by running analyses of molecular variance (AMOVA, Excoffier et al., 1992) using 155 ARLEQUIN 3.3 (Excoffier \& Lischer, 2010).

156

\section{Microsatellite genotyping}

158 A total of 169 of the 174 samples (Appendix 1) were genotyped by PCR amplification at 14 microsatellite 159 loci (Ans02, Ans04, Ans07, Ans13, Ans17, Ans18, Ans21, Ans24, Ans25, Aal 1 1b, Aph12b, Aph19b, 160 Smo7b, Hhi 1 1b) that had previously been isolated and tested in Anser anser (Weiß et al., 2008). We used 161 PCR reactions, thermal profiles, fluorescent dye and multiplex sets, as indicated by Weiß et al. (2008).

162 Microsatellite genotyping was performed on an ABI Prism 3100 Genetic Analyzer (Applied Biosystems) 163 using the Macrogen Inc. GenScan service (Seoul, Korea). Negative controls were included for 164 amplification procedures. Results were analysed in GENEMAPPER v. 4.0 (Applied Biosystems, Foster 165 City, California).

166 Allele frequencies, standard diversity indices, observed heterozygosity $\left(\mathrm{H}_{\mathrm{O}}\right)$ and expected 167 heterozygosity $\left(\mathrm{H}_{\mathrm{E}}\right)$ for each locus and population were calculated in GENALEX v. 6 (Peakall \& Smouse, 168 2006).

169 We performed a factorial correspondence analysis (FCA) of individual multilocus scores in 170 GENETIX 4.05 (Belkhir et al., 2004) to describe genetic clusters. 
172 the Hardy-Weinberg equilibrium (HWE) at each locus and within each population. Statistics were 173 computed with Markov chain parameters at default settings.

174 We used ARLEQUIN 3.5 (Excoffier \& Lischer, 2010) to estimate the genetic variance within and 175 between populations through a hierarchical Analysis of Molecular Variance (AMOVA; Excoffier et al., 176 1992).

177 The genetic structure of the sampled populations was computed using Bayesian clustering 178 procedures in Structure v. 2.3 (Pritchard, Stephens \& Donnelly, 2000; Falush, Stephens \& Pritchard, 179 2003), without prior information about the origin and under an admixed model. Analyses were performed 180 where $\mathrm{K}=1-10$ with $50 \times 10^{5}$ iterations following a burn-in period of $50 \times 10^{4}$ iterations; all simulations 181 were independently replicated four times for each K. We explored the optimal value of K by plotting the 182 average estimated $\operatorname{LnP}(\mathrm{D})$ (Ln probability of the data) and using $\Delta \mathrm{K}$ statistics (Evanno, Regnaut \& 183 Goudet, 2005) calculated using Structure Harvester 0.6.93 (Earl \& VonHoldt, 2012). ClumpP v. 184 1.1.2 (Jakobsson \& Rosenberg, 2007) and DisTRUCT v. 1.1 (Rosenberg, 2003) were used to align the 185 cluster membership coefficients of the five STRUCTURE runs and display the results. \& Luikart, 1996) for two models: the infinite alleles (IAM, Maruyama and Fuerst, 1985) and the twophase model (TPM, Di Rienzo et al., 1994). 3.0.3 (Wilson and Rannala 2003). We performed 10 runs of $9 \times 10^{6}$ iterations with a burn-in of $10 \%$, and a

191 sampling frequency of 200. Delta values were varied for all parameters, and resulted in acceptance rates 192 between $40 \%$ and $60 \%$ of the total iterations (Wilson \& Rannala, 2003).

194 1995; Rousset, 2008; see also Legendre and Fortin, 2010); FST and geographic distance were compared 195 using 1000 random permutations. The geographic distance connecting samples was represented by 196 Euclidean (linear geographic) distances computed in QGIS (QGIS Development Team, 2014). 
198 Results

199

$200 m t D N A$

201 The mtDNA marker sequences (CR1 D-Loop 288 bp) showed 23 haplotypes defined by ten

202 polymorphic sites and distributed in eight locations (Appendix 2). Among the 23 haplotypes found

203 (GenBank accession numbers KT276333 - KT276355), 14 haplotypes were shared by 2-47 individuals.

204 According to the study areas, we found a total of nine private haplotypes, the majority of which occurred

205 in the Landes (SW France) population (Table1, Appendix 2). The diversity indices for mtDNA revealed

206 moderate levels of genetic variation in the greylag goose in all sampled areas (Table 1). Haplotype

207 diversity showed high values in all groups (range 0.798-0.949) except in breeding areas in Finnmark

$208(0.564 \pm 0.13 \mathrm{SD})$ and Vega, Norway $(0.170 \pm 0.10 \mathrm{SD})$.

209 The genetic distances recorded in Norway, northern France and the Netherlands were low (range

210 0.012-0.013). A slightly higher genetic distance was observed in south-west France in comparison to all

211 other sampling sites (ranges $0.018-0.022$ ), while the two breeding sites in Norway were genetically very

212 close (Table 2).

213 The NJ tree shows that clades are composed of a wide variety of different geese from different

214 areas. Individuals from each site were present in different branches (Fig. 2). Besides, none of the clades

215 grouped together individuals originating from the same areas. About half the individuals were grouped

216 together with the GenBank reference sequence relating to the anser subspecies, while the remainder were

217 either grouped with the sequence relating to the rubrirostris subspecies or differed clearly from both

218 subspecies. Very similar topologies were obtained from trees generated with other tree-building methods

219 (MP and ML; not shown).

220 The haplotype median-joining network (Fig. 2) was concordant with the phylogenetic tree

221 topology and did not reveal any geographic structures. The number of mutations separating the different

222 haplotypes was low $(\max =10)$. 
Whilst $88.85 \%$ of the total genetic variance shown in hierarchical AMOVA was within

224 populations, the remaining $11.15 \%$ occurred among populations. This indicates a small differentiation 225 between the sampled areas.

226 Non-significant raggedness indices indicated a good fit to a model of population expansion in all 227 sampled areas. Mismatch distribution results also suggested a population expansion in all areas except the 228 Gironde region $(\mathrm{P}=0.044)$ and Finnmark $(\mathrm{P}=0.042)$ (Appendix 4). Fu's FS value (Table 1) was only 229 significantly negative for the Oise region, and was consistent with a demographic expansion for all other 230 areas.

\section{Microsatellites}

Among the 15 microsatellites previously isolated by Weiß et al. (2008) only Ans26 was shown to be monomorphic in all investigated individuals. The remaining 14 polymorphic microsatellite loci showed 2-12 different alleles per locus ( $n=169$ individuals; Table 3$)$.

Observed and expected heterozygosities were moderate, with similar values in each sampled population $\left(\mathrm{H}_{\mathrm{o}}\right.$ ranging from 0.374 to 0.484 and $\mathrm{H}_{\mathrm{e}}$ from 0.433 to 0.549$)$. Geese from the Landes wintering area exhibited the highest number of private alleles $(n=3$, Appendix 3$)$.

Genetic structure was visualized using factorial correspondence analysis (FCA) in each population (Fig. 3). The plot shows an absence of phylogeographic structure in the different investigated 241 areas: individuals from different areas overlap, with the exclusion of four samples from Nord, one sample 242 from Finnmark, one from Oise and one from Gironde.

Significant departures from HWE, due to heterozygote deficit and related to positive Fis values, 244 were observed in all populations (Table 3, Appendix 3).

AMOVA analyses showed that $97.9 \%$ of the total genetic variance in geese was significantly 246 distributed within populations $(\mathrm{p}<0.001)$, while only $2.1 \%$ was distributed among populations. 247 Overall fixation index FST from AMOVA was 0.02105, indicating a low differentiation between areas. 
249 showed a maximum $\Delta K$ at $K=4$, while likelihood values reached a plateau at $K=7$ (Fig. 4). Graphs

250 show no evidence of phylogeographic structure across sampled populations, whatever the K value. With

$251 \mathrm{~K}=4$, only 23 individuals with individual qi values were each assigned to a single cluster: two

252 individuals from Finnmark, three from Vega and one from Gironde were attributed to cluster 1; one

253 individual from Netherland, two from Finnmark, six from Vega, one from Charente Maritime, two from

254 Gironde and one from Landes were attributed to cluster 2; two individuals from Oise and two from

255 Landes were assigned to cluster 3 . All other birds had a highly mixed genotype. In the case of $\mathrm{K}=7$, five

256 other individuals, one from Finnmark, Charente Maritime and Gironde and two from Vega, were assigned

257 to the same cluster with qi $>0.90$.

258 Bottleneck events tested under IAM revealed a significant excess of heterozygotes (evidence of a

259 recent bottleneck) in Nord, Landes and Oise populations (Wilcoxon sign-rank tests, all $\mathrm{P}<0.05$ ).

260 Analysis under TPM only confirmed a recent bottleneck event for the Nord population $(\mathrm{P}<0.05)$.

261

BAYESASS detected a low migration rate among localities and a high proportion of local

262 individuals ( $>68 \%$, Table 4), suggesting that the flows among different areas were limited. Indeed, the 263 analysis found a high proportion of local geese in six populations $(>90 \%)$. In two cases, gene flow 264 appears to be strongly asymmetrical, with many birds moving from Charente Maritime to the Netherlands $265(20.7 \% \pm 3.79 \mathrm{SD})$ and from Oise to Gironde $(20.2 \% \pm 3.44 \mathrm{SD})$, but not in the opposite direction $(1.5 \%$ 266 and $1.1 \%$ respectively).

267 The Mantel test calculated on geographic and genetic distances yielded a non-significant 268 correlation coefficient $(\mathrm{r}=0.107 ; \mathrm{P}=0.08)$, suggesting that there is no strong relationship between 269 geographic and genetic distances.

\section{Discussion}


274 In this study we used a pool of 14 microsatellites isolated by Weiß et al. (2008) for greylag goose 275 parentage in the long-established goose population at Konrad Lorenz Research Station, Grünau, Austria 276 (Lorenz, 1966; Hirschenhauser, Möstl \& Kotrschal, 1999). We found that these microsatellites can be 277 successfully employed for geese sampled in a wide range of localities along the European Atlantic 278 flyway. This is the first large scale study showing a moderate genetic variability of mtDNA and nuclear 279 DNA in all French wintering areas and in the Netherlands, with slightly lower mtDNA variability in the

280 Norwegian breeding sites. A moderate genetic variability in the greylag goose was already reported two 281 decades ago by Blaakmeer (1995), and has been found in other species of geese (Anser erythropus:

282 Ruokonen et al., 2004; Ruokonen et al., 2010; Anser brachyrhynchus: Ruokonen et al., 2005). Low 283 genetic variability also seems to be typical for other Anatidae species (Aythya ferina: Liu et al., 2011; 284 Aythya fuligula: Liu et al., 2012). Interestingly, our results show that the genotypes deviated from Hardy285 Weinberg expectation at eight loci, and in all study areas deviation was due to heterozygote deficiency. 286 Besides, the deficit of heterozygotes matched with positive FIS values. These results could be related to

287 different factors, such as population substructuring or recent population growth (Cornuet \& Luikart, 288 1996).

Genetic distances between the different areas were low (range from 0.012 to 0.017 ) and the 290 hierarchical AMOVA showed genetic variance to mainly occur within populations. These findings could 291 be explained by a small differentiation between the sampled areas and a general admixture of greylag 292 goose populations in our western European study region. However, it should be taken into account that 293 genetic divergences in geese are characteristically very low, with the lowest interspecific divergence 294 reported here for avian species (Ruokonen, Kvist \& Lumme, 2000). The genetic tree shows that different 295 branches include individuals from each sampling area. No single branch exclusively grouped together 296 individuals originating from the same zone. Moreover, birds sampled in the western part of the breeding 297 range, traditionally ascribed to the anser subspecies, were not separated from birds collected in the 298 eastern part that were traditionally assigned to the rubrirostris subspecies (Kampe-Persson, 2002). Birds

299 from Iceland, Scotland and coastal Norway have been sometimes separated as a race, sylvestris, classified 
300 in the anser group (Snow, Perrins \& Cramp, 1998). Although Icelandic and Scottish birds were absent

301 from this study, individuals from the Norwegian west coast did not appear to be clearly distinct from

302 other European geese. Our present results slightly differ from the findings of Blaakmeer's (1995)

303 preliminary study, which reported genetic differences between breeders in two Dutch sites in comparison

304 to breeding sites in south Sweden and Norway. However, Blaakmeer's analyses show significant

305 differences for only one of six minisatellites, in only two of the three Dutch areas studied.

306 Interestingly, the ANS19 sequence was recently found in the white Roman goose in Taiwan. This

307 race is widely bred for commercial purposes, and has been found to originate from the European species

308 (Anser anser, Wang et al., 2010). Our data confirm the presence of this sequence in Europe, particularly

309 in the breeding population of the Norwegian west coast.

310 Haplotypes ANS02, ANS08, ANS11, ANS14 and ANS23 were only found during the winter in

311 France, and were absent in Norway and the Netherlands: this result could indicate that some of the geese

312 arriving in France came from areas we did not sample on the breeding grounds. Ring recoveries and

313 resighting records indicate that these birds probably originated from northern Germany, Poland, Denmark

314 and Sweden (Nilsson et al., 2013).

315 The haplotype network confirmed the tree configuration. There was no geographic pattern, and

316 the number of mutations separating the different nodes was very low. This confirms the low genetic

317 distance between our studied populations in the large north-western European population (as defined by

318 Delany and Scott, 2006), and may reflect the rapid population expansion (Aris-Brosou \& Excoffier, 319 1996).

320 Data obtained from nuclear DNA by microsatellites were in accordance with findings from 321 mtDNA. As the mtDNA is uniparentally inherited whereas microsatellites are part of the biparentally 322 inherited nuclear DNA, a difference between the two genomes would have indicated the presence of sex-

323 biased dispersal (Fahey, Ricklefs \& Dewoody, 2014). However, sex-biased dispersal seems to be unlikely

324 in greylag geese for three reasons: the family unit remains together at least until autumn migration, the

325 birds tend to pair before returning to the breeding grounds, and males and females have long-term pair 
326 bonds (Rohwer \& Anderson, 1988; Doherty et al., 2002). Sex-biased dispersal in birds is probably not a

327 species constant (Clarke et al., 1997). Within Anatidae in general, sex-biased dispersal was not detected

328 in several species (Doherty et al., 2002; Mabry et al., 2013), while it was found in some species such as

329 the white-fronted goose (Anser erythropus, Ruokonen et al., 2010), the common eider (Somateria

330 mollissima, Paulus \& Tiedemann, 2003), and the spectacled eider (Somateria fisheri, Scribner et al., 331 2001).

332 In our study of microsatellites, individuals from different geographic localities were found to be 333 combined in the Factorial Correspondence Analysis representation. Bayesian structure analysis resulted in 334 a best combination of four or seven groups, according to $\Delta \mathrm{K}$ and $\mathrm{LnP}(\mathrm{D})$ methods respectively. As seen in 335 our previous analyses, no geographic clustering was observed inside these STRUCTURE groups. Almost all 336 individuals, with few exceptions, showed admixed genotype regardless of the number of groups 337 considered in the analysis.

338 The high mixing of genotypes and the lack of geographic structure among our studied populations 339 could be interpreted in the light of the data obtained through ringing activity and the extensive neck340 banding programme carried out in Scandinavia from 1984 to 2004 (Nilsson, 2007; Voslamber, Knecht \& 341 Kleijn, 2010). Ring recoveries and visual observations showed that Scandinavian geese breeding in 342 different zones can admix not only in the moulting areas (Nilsson, Kahlert \& Persson, 2001) but also 343 along the European Atlantic flyway, i.e. in the Netherlands (Voslamber, Knecht \& Kleijn, 2010), France

344 (Fouquet, Schricke \& Fouque, 2009; Nilsson et al., 2013) and Spain (Ramo et al., 2012) where they can

345 form pairbonds. Besides this Scandinavian data, the monitoring of collared and/or ringed individuals

346 performed in other European areas showed the presence of birds in France originating from Germany, the

347 Czech Republic and Poland. Populations that breed further east do not seem to reach France in winter

348 (Kampe-Persson, 2010). From these data it appears that the greylag geese that cross France or winter 349 there could result from a mixture of populations from different areas.

350 Our findings are somewhat unexpected if one assumes that the fragmentation of breeding 351 populations into separate areas during the first part of the last century (Hagemeijer \& Blair, 1997; Kampe- 
352 Persson, 2002), should have led to an increase in genetic structure. Moreover, birds breeding in the

353 Netherlands have recently become highly sedentary (Fox et al., 2010), and this may also have contributed

354 to the increase in genetic structure (Blaakmeer, 1995). However, a genetic panmixia could have been

355 promoted by the widespread amateur breeding and selling of geese, and the recent increase and dispersal

356 of several wild goose populations (Klok et al., 2010). In particular, geese with pink bills and legs, most

357 probably rubrirostris subspecies, have been spreading in Europe over the last few decades; their natural

358 flyway toward wintering areas crosses other European countries (from Russia to Hungary, the Balkan

359 States and Italy) but does not reach France.

360 The breeding of geese is a widespread practice among amateurs, who can easily obtain both

361 goslings and adults with a grey wild appearance (B. and G. Vaschetti, pers. comm.). In some cases geese

362 were released as part of assisted restoring projects and are now indistinguishable from the wild

363 individuals (Kampe-Persson, 2010). Besides, birds with white plumage are common in breeding farms. In

364 Asia, white geese are mostly descendants of the swan goose (Anser cygnoides). Even if descendants of

365 Anser anser can also be found there, they are usually farmed in Europe (Wang et al., 2010). Although the

366 two species can hybridize in captivity, hybrids can be detected through karyotype (Shahin, Ata \& Shnaf,

367 2014) or genotype examinations (Sun et al., 2014). The contribution of escaped white form geese to the

368 admixture observed in wild populations is probably low given the high assortative mating of wild greylag

369 geese, their long-term monogamous pair bonds, female-bonded clan structure, long parent-offspring

370 relationships, and elaborate patterns of mutual social support (Hirschenhauser et al., 2000; Kotrschal,

371 Scheiber \& Hirschenhauser, 2010).

372 Our findings on the greylag goose genetic admixture are similar to those reported in the snow

373 goose (Chen caerulescens, Avise et al., 1992) and the barnacle goose (Branta leucopsis, Jonker et al.,

374 2013). Despite the high rate of site philopatry seen in the snow goose, which has also shown a high

375 increase in population over the last decades, mtDNA markers showed no clear distinctions between

376 nesting populations across species range (Avise et al., 1992). The barnacle goose recently changed its

377 migratory traditions, and new populations differing in migratory distance were observed. Genetic data 
378 showed an admixture between all populations, despite the assumed traditions of migration within areas

379 and the presence of a newly established nonmigratory population in the Netherlands (Jonker et al., 2013).

380 A lack of genetic structure in wintering areas was also found in four species of Anatidae, namely the

381 common pochard, the mallard, the king eider and the tufted duck (Pearce et al., 2004; Liu, Keller \&

382 Heckel, 2011, 2012; Kraus et al., 2013; Liu et al., 2013), and in the black-tailed godwit (Limosa limosa,

383 Lopes et al., 2013). The mixing of breeding populations in wintering areas is believed to be a common

384 phenomenon in birds, because the breeding ranges of most species are considerably larger than their

385 wintering ranges (Winker \& Graves, 2008). However, migratory populations vary in the degree to which

386 individuals from distinct breeding localities mix on different sites. Therefore, to understand population

387 demographics and genetic diversification, it is crucial to pinpoint which populations mix on breeding and

388 wintering grounds (Chabot et al., 2012).

389 Our DNA-based estimates of migration during the wintering period indicated a low rate of

390 exchange between our sampled areas. In five of eight areas the vast majority of individuals (86-95\%) did

391 not switch among the different zones, and a moderate exchange (about 20\%) was only observed from

392 Charente Maritime to the Netherlands and from Oise to Gironde. These results seem to support the

393 hypothesis that the French wintering birds arrive from various areas, including zones that are not sampled

394 here (i.e. Germany, Poland), while the contribution of the Norwegian population represents only a portion

395 of the whole assemblage (Fouquet, Schricke \& Fouque, 2009). This low exchange rate is also supported

396 by evidence of great changes in spatial ecology recorded in 28 GPS tagged western European greylag

397 geese, i.e. very low home ranges on wintering areas $\left(<8.9 \pm 2.5 \mathrm{~km}^{2}\right)$ compared to $2-5$ fold values obtained

398 in staging areas during migratory and premigratory periods (Boos unpublished data).

399 Our data show evidence of genetic bottlenecks in just three groups under IAM, all located along

400 the same flyway (Nord, Oise and Landes), and in a single case (Nord) under TPM. The discrepancy

401 between IAM and TPM could be related to the different ability of the mutation models to detect

402 bottleneck events. Empirical data suggest that TPM is the most appropriate model for microsatellite loci

403 (Ellegren, 2000, 2004) while IAM results should be interpreted with caution (Cornuet \& Luikart, 1996). 
404 We did not observe any sign of bottlenecks in the breeding populations: this indicates that greylag geese

405 have never suffered any severe demographic reduction, even at the beginning of the past century when the

406 number of breeding individuals was low in several European areas (Kampe-Persson, 2002).

407 Greylag goose populations are steadily increasing in north-western Europe (Kampe-Persson,

408 2002). The large number of geese in some areas is now in conflict with agricultural interests, since geese

409 not only forage in natural environments but also forage on crop fields, and claims for a need to control the

410 species are widespread (Klok et al., 2010). Our data suggest that the migratory geese harvested over

411 France (about 20000 geese/year, see Landry and Migot, 2000) show a relatively high diversity of origin.

412 From this result it is difficult to conclude if there is a strong impact on a specific breeding population.

413 Future studies could analyze other European breeding and wintering areas; this could clarify the status of

414 the different populations and subspecies on the continent (the main Anser anser anser and A. a.

415 rubrirostris, as well as the sylvestris forms from Iceland, Scotland and Norway), and help to build an

416 effective international management strategy for this migratory species (Chabot et al., 2012).

417

418 Acknowledgements - Our thanks to all the hunters who provided feather samples from France, to

419 Wilmer Remijnse who provided feather samples from Netherlands, and to Paul Shimmings for his field

420 assistance in Norway. We are grateful to Bruno and Gabriella Vaschetti which provided useful

421 information on geese farming, the International Union for Conservation of Nature IUCN which provided

422 an updated distribution map, and to Joanna Lignot-Munro for language editing.

423

424

425

426

427

428

429

430

431

432

\section{References}

Andersson Å, Follestad A, Nilsson L, Persson H. 2001. Migration patterns of Nordic Greylag Geese Anser anser. Ornis Svecica 11:19-58.

Aris-Brosou S, Excoffier L. 1996. The impact of population expansion and mutation rate heterogeneity on DNA sequence polymorphism. Molecular Biology and Evolution 13:494-504.

Avise JC, Alisauskas RT, Nelson WS, Ankney CD. 1992. Matriarchal population genetic structure in an avian species with female natal philopatry. Evolution 46:1084-1096. 
Bandelt H-J, Forster P, Rohl A. 1999. Median-Joining networks for inferring intraspecific phylogenies. Molecular biology and evolution 16:37-48.

Belkhir K, Borsa P, Chikhi L, Raufaste N, Bonhomme F. 2004. GENETIX 4.05, logiciel sous Windows TM pour la génétique des populations. Montpellier, France.: Laboratoire Genome, Populations, Interactions, CNRS UMR 5000, Université de Montpellier II.

BirdLife International B. 2004. Birds in Europe, population estimates, trends and conservation status. Cambridge.

Blaakmeer K. 1995. Genetic variation within the west European population of the Greylag goose (Anser anser). Groningen.

Boos M, Schricke V, Green AJ, Shimmings P, Lefranc H, Amat JA, Ramo C, Follestad A. 2012. Migration of Greylag Geese tagged in Norway and Spain using GPS devices: first results from a new joint European Research Program. In: 14th Meeting of the Goose Specialist Group. 8. Steinkjer, Norway.

Burnham KP, Anderson DR. 2004. Multimodel Inference: Understanding AIC and BIC in Model Selection. Sociological Methods \& Research 33:261-304.

Chabot AA, Hobson KA, Van Wilgenburg SL, McQuat GJ, Lougheed SC. 2012. Advances in linking wintering migrant birds to their breeding-ground origins using combined analyses of genetic and stable isotope markers. PloS one 7:e43627.

Clarke AL, Saether B-E, Roskaft E. 1997. Sex biases in avian dispersal: a reappraisal. Oikos 79:429-438.

Comolet-Tirman J. 2009. L'Oie cendrée Anser anser en France et en Europe. Dynamique de population, statuts de conservation, voies de migration et dates de migration prénuptiale. Service du Patrimoine Naturel Département Ecologie et Gestion de la Biodiversité.

Cornuet JM, Luikart G. 1996. Description and power analysis of two tests for detecting recent population bottlenecks from allele frequency data. Genetics 144:2001-14.

Cramp S. 1977. Handbook of the birds of Europe, the Middle East, and North Africa. The birds of the Western Palearctic, vol. 1. Oxford: Oxford University Press.

Delany S, Scott D. 2006. Waterbird population estimates, Fourth Edition. Wageningen, the Netherlands.: Wetland International.

Doherty PF, Nichols JD, Tautin J, Voelzer JF, Smith GW, Benning DS, Bentley VR, Bidwell JK, Bollinger KS, Brazda AR, Buelna EK, Goldsberry JR, King RJ, Roetker FH, Solberg JW, Thorpe PP, Wortham JS, Service USG, Wildlife P, Road BF. 2002. Sources of variation in breeding-ground fidelity of mallards (Anas platyrhynchos). Behavioral Ecology 13:543-550.

Earl DA, VonHoldt BM. 2012. STRUCTURE HARVESTER: a website and program for visualizing STRUCTURE output and implementing the Evanno method. Conservation Genetics Resources 4:359-361.

Ellegren H. 2000. Microsatellite mutations in the germline: implications for evolutionary inference. Trends in Genetics 16:551-558.

Ellegren H. 2004. Microsatellites: simple sequences with complex evolution. Nature reviews. Genetics 5:435-45. 
468

Evanno G, Regnaut S, Goudet J. 2005. Detecting the number of clusters of individuals using the software STRUCTURE: a simulation study. Molecular Ecology 14:2611-2620.

Excoffier L, Lischer HEL. 2010. Arlequin suite ver 3.5: a new series of programs to perform population genetics analyses under Linux and Windows. Molecular Ecology Resources 10:564-567.

Excoffier L, Smouse PE, Quattro JM. 1992. Analysis of molecular variance inferred from metric distances among DNA haplotypes: application to human mitochondrial DNA restriction data. Genetics 131:479-491.

Fahey AL, Ricklefs RE, Dewoody JA. 2014. DNA-based approaches for evaluating historical demography in terrestrial vertebrates. Biological Journal of the Linnean Society 112:367-386.

Falush D, Stephens M, Pritchard JK. 2003. Inference of population structure using multilocus genotype data: linked loci and correlated allele frequencies. Genetics 164:1567-1587.

Felsenstein J. 1988. Phylogenies from molecular sequences: inference and reliability. Annual Review of Genetics 22:521-565.

Felsenstein J. 2005. PHYLIP (Phylogeny Inference Package) version 3.6.

Fouquet M. 1991. Migration et hivernage de l'oie cendrée (Anser anser) en France. Rôle et importance du CentreOuest. Oiseau et la Revue Francaise d'Ornithologie 61:111-130.

Fouquet M, Schricke V, Fouque C. 2009. Greylag Geese Anser anser depart earlier in spring: an analysis of goose migration from western France over the years 1980 - 2005. Wildfowl 59:143-151.

Fox AD, Ebbinge BS, Mitchell C, Heinicke T, Aarvak T, Colhoun K, Clausen P, Dereliev S, Faragó S, Koffijberg K, Kruckenberg H, Pihl S, Jeugd HVANDER. 2010. Current estimates of goose population sizes in western Europe, a gap analysis and an assessment of trends. Ornis Svecica 20:115-127.

Hagemeijer EJM, Blair MJ. 1997. The EBCC Atlas of European Breeding Birds: Their Distribution and Abundance. London: T. \& A. D. Poyser.

Hall T. 1999. BioEdit: a user-friendly biological sequence alignment editor and analysis program for Windows 95/98/NT. Nucleic Acids Symposium Series 41:95-98.

Hirschenhauser K, Mo E, Bernard Ã, John W, Kurt D. 2000. Endocrine and behavioural responses of male Greylag Geese Anser anser to pairbond challenges during the reproductive season. Ethology 106:63-77.

Hirschenhauser K, Möstl E, Kotrschal K. 1999. Seasonal patterns of sex steroids determined from feces in different social categories of Greylag geese (Anser anser). General and comparative endocrinology 114:67-79.

IUCN 2015. The IUCN Red List of threatened species. Version 2015.1. http://www.iucnredlist.org. Downloaded on 11 May 2015.

Jakobsson M, Rosenberg NA. 2007. CLUMPP: a cluster matching and permutation program for dealing with label switching and multimodality in analysis of population structure. Bioinformatics 23:1801-1806.

Johnsen A, Rindal E, Ericson PGP, Zuccon D, Kerr KCR, Stoeckle MY, Lifjeld JT. 2010. DNA barcoding of Scandinavian birds reveals divergent lineages in trans-Atlantic species. Journal of Ornithology 151:565-578. 
502

503

504

505

506

507

508

509

510

511

512

513

514

515

516

517

518

519

520

521

522

523

524

525

526

527

528

529

530

531

532

533

534

535

536

537

538

Jonker RM, Kraus RHS, Zhang Q, van Hooft P, Larsson K, van der Jeugd HP, Kurvers RHJM, van Wieren SE, Loonen MJJE, Crooijmans RPMA, Ydenberg RC, Groenen MAM, Prins HHT. 2013. Genetic consequences of breaking migratory traditions in barnacle geese Branta leucopsis. Molecular ecology 22:5835-5847.

Kampe-Persson H. 2002. Anser anser Greylag Goose. BWP Update 4:181-216.

Kampe-Persson H. 2010. Naturalised geese in Europe. Ornis Svecica 20:155-173.

Klok C, Schekkerman H, Willems F, Ebbinge B, van Turnhout C. 2010. Analysis of population development and effectiveness of management in resident greylag geese Anser anser in the Netherlands. Animal Biology 60:373-393.

Kotrschal K, Scheiber IBR, Hirschenhauser K. 2010. Individual performance in complex social systems: the greylag goose example. In: Kappeler P ed. Animal Behaviour: Evolution and Mechanisms. Berlin: Springer Verlag, 121-148.

Kraus RHS, van Hooft P, Megens H-J, Tsvey A, Fokin SY, Ydenberg RC, Prins HHT. 2013. Global lack of flyway structure in a cosmopolitan bird revealed by a genome wide survey of single nucleotide polymorphisms. Molecular Ecology 22:41-55.

Landry P, Migot P. 2000. Enquête nationale sur les tableaux de chasse à tir: saison 1998/1999. Faune Sauvage Cahiers techniques $n^{\circ} 251$.

Legendre P, FortinM-J. 2010. Comparison of the Mantel test and alternative approaches for detecting complex multivariate relationships in the spatial analysis of genetic data. Molecular Ecology Resources 10:831-844.

Librado P, Rozas J. 2009. DnaSP v5: a software for comprehensive analysis of DNA polymorphism data. Bioinformatics 25:1451-1452.

Liu S, Li Y, Lu J, Su X, Tang M, Zhang R, Zhou L, Zhou C, Yang Q, Ji Y, Yu DW, Zhou X. 2013. SOAPBarcode: revealing arthropod biodiversity through assembly of Illumina shotgun sequences of PCR amplicons. Methods in Ecology and Evolution 4:1142-1150.

Liu Y, Keller I, Heckel G. 2011. Range-wide genetic population structure of common pochard (Aythya ferina): a potentially important vector of highly pathogenic avian influenza viruses. Ecology and Evolution 1:529-545.

Liu Y, Keller I, Heckel G. 2012. Breeding site fidelity and winter admixture in a long-distance migrant, the tufted duck (Aythya fuligula). Heredity 109:108-116.

Liu Y, Keller I, Heckel G. 2013. Temporal genetic structure and relatedness in the Tufted Duck Aythya fuligula suggests limited kin association in winter. Ibis 155:499-507.

Lopes RJ, Alves JA, Gill JA, Gunnarsson TG, Hooijmeijer JCEW, Lourenco PM, Masero JA, Piersma T, Potts PM, Rabacal B, Reis S, Sanchez-Guzman JM, Santiago-Quesada F, Villegas A. 2013. Do different subspecies of Black-tailed Godwit Limosa limosa overlap in Iberian wintering and staging areas? Validation with genetic markers. Journal of Ornithology 154:35-40.

Lorenz KZ. 1966. The triumph ceremony of the Greylag Goose, Anser anser. Philosophical Transactions of the Royal Society B: Biological Sciences 251:477-477.

Mabry KE, Shelley EL, Davis KE, Blumstein DT, Van Vuren DH. 2013. Social mating system and sex-biased dispersal in mammals and birds: a phylogenetic analysis. PloS one 8:e57980. 
Maruyama T, Fuerst PA. 1985. Population bottlenecks and non equilibrium models in population genetics. II. Number of alleles in a small population that was formed by a recent bottleneck. Genetics 111:675-689.

Nilsson L. 2007. The Nordic Greylag Goose (Anser anser) Project. Aves 44:177 - 184.

Nilsson L, Follestad A, Guillemain M, Schricke V, Voslamber B. 2013. France as a staging and wintering area for Greylag Geese Anser anser. Wildfowl 63:24-39.

Nilsson L, Kahlert J, Persson H. 2001. Moult and moult migration of Greylag Geese Anser anser from a population in Scania, south Sweden. Bird Study 48:129-138.

Paulus KB, Tiedemann R. 2003. Ten polymorphic autosomal microsatellite loci for the Eider duck Somateria mollissima and their cross-species applicability among waterfowl species (Anatidae). Molecular Ecology Notes 3:250-252.

Peakall R, Smouse PE. 2006. GENALEX 6: genetic analysis in Excel. Population genetic software for teaching and research. Molecular Ecology Notes 6:288-295.

Pearce JM, Talbot SL, Pierson BJ, Petersen MR, Scribner KT, Dickson DL, Mosbech A. 2004. Lack of spatial genetic structure among nesting and wintering King Eiders. The Condor 106:229-240.

Persson H. 1993. Arrival patterns of Greylag Geese Anser anser in the Guadalquivir Marismas. Wildfowl 44:19-23.

Pistorius PA., Follestad A, Nilsson L, Taylor FE. 2007. A demographic comparison of two Nordic populations of Greylag Geese Anser anser. Ibis 149:553-563.

Pistorius PA, Follestad A, Taylor FE. 2006. Declining winter survival and fitness implications associated with latitudinal distribution in Norwegian Greylag Geese Anser anser. Ibis 148:114-125.

Posada D. 2008. jModelTest: phylogenetic model averaging. Molecular biology and evolution 25:1253-1256.

Pritchard JK, Stephens M, Donnelly P. 2000. Inference of population structure using multilocus genotype data. Genetics 155:945-959.

QGIS Development Team T. 2014. QGIS Geographic Information System. Open Source Geospatial Foundation Project.

Rambaut A. 2008. FigTree: Tree Figure Drawing Tool Version 1.3. 1 2006-2009. Institute of Evolutionary Biology, University of Edinburgh. http://tree.bio.ed.ac.uk.

Ramo C, Amat JA, Calderón J, Gómez-Crespo E, Navedo JG, Green AJ, Jubete F, Masero JA, Palacios J, Rodríguez-Alonso M, Boos M, Schricke V. 2012. Distribution and population trends of wintering Greylag Geese in Spain. In: 14th Meeting of the Goose Specialist Group. 28.

Raymond M, Rousset F. 1995. GENEPOP (version 1.2): population genetics software for exact tests and ecumenicism. Journal Of Heredity 86:248-249.

Di Rienzo A, Peterson AC, Garza JC, Valdes AM, Slatkin M, Freimer NB. 1994. Mutational processes of simplesequence repeat loci in human populations. Proceedings of the National Academy of Sciences of the United States of America 91:3166-3170. 
573

574

575

576

577

578

579

580

581

582

583

584

585

586

587

588

589

590

591

592

593

594

595

596

597

598

599

600

601

602

603

604

605

606

607

Rohwer FC, Anderson MG. 1988. Female-biased philopatry, monogamy, and the timing of pair formation in migratory waterfowl. In: Johnston E, Richard F eds. Current Ornithology v.5. Boston: Springer US, 187-221.

Rosenberg NA. 2003. Distruct: a program for the graphical display of population structure. Molecular Ecology Notes 4:137-138.

Rousset F. 2008. GENEPOP'007: a complete reimplementation of the GENEPOP software for Windows and Linux. Molecular ecology resources 8:103-106.

Ruokonen M, Kvist L, Aarvak T, Markkola J, Morozov V, Øien IJ, Jr EES, Tolvanen P. 2004. Population genetic structure and conservation of the lesser white-fronted goose Anser erythropus. Conservation Genetics:501512 .

Ruokonen M, Aarvak T, Chesser RK, Lundqvist A-C, Merilä J. 2010. Temporal increase in mtDNA diversity in a declining population. Molecular Ecology 19:2408-2417.

Ruokonen M, Aarvak T, Madsen J. 2005. Colonization history of the high-arctic pink-footed goose Anser brachyrhynchus. Molecular Ecology 14:171-8.

Ruokonen M, Kvist L, Lumme J. 2000. Close relatedness between mitochondrial DNA from seven Anser goose species. Journal of Evolutionary Biology 13:532-540.

Saitou N, Nei M. 1987. The neighbor-joining method: a new method for reconstructing phylogenetic trees. Molecular biology and evolution 4:406-425.

Scribner KT, Petersen MR, Fields RL, Talbot SL, Pearce JM, Chesser RK. 2001. Sex-biased gene flow in Spectacled Eiders (Anatidae): inferences from molecular markers with contrasting modes of inheritance. Evolution 55:2105-2115.

Shahin AAB, Ata ATM, Shnaf ASMA. 2014. Karyotype and C-banding pattern of the domestic geese Anser anser populations (Aves: Anatidae) in Egypt. Folia biologica 62:49-58.

Snow DW, Perrins CM, Cramp S. 1998. The Complete Birds of the western Palaearctic: On CD-ROM. Oxford: Oxford University Press.

SOVON. 1987. Atlas van de Nederlandse vogels. Nederland, Leiden.: SOVON Vogelonderzoek Nederland, Arnhem NL.

Sun J, Zhang S, He D-Q, Chen S-Y, Duan Z-Y, Yao Y-G, Liu Y-P. 2014. Matrilineal genetic structure of domestic geese. Journal of Poultry Science 51:130.

Tamura K, Peterson D, Peterson N, Stecher G, Nei M, Kumar S. 2011. MEGA5: Molecular Evolutionary Genetics Analysis using Maximum Likelihood, Evolutionary Distance, and Maximum Parsimony Methods. Molecular Biology and Evolution 28:2731-2739.

Tamura K, Nei M. 1993. Estimation of the number of nucleotide substitutions in the control region of mitochondrial DNA in humans and chimpanzees. Molecular biology and evolution 10:512-526.

Voslamber B, Knecht E, Kleijn D. 2010. Dutch Greylag Geese Anser anser: migrants or residents? Ornis Svecica 20:207-214.. 
608 Wang CM, Way TD, Chang YC, Yen NT, Hu CL, Nien PC, Jea YS, Chen LR, Kao JY. 2010. The origin of the 609 white Roman goose. Biochemical genetics 48:938-43.

610 Weiß BM, Poggemann K, Olek K, Foerster K, Hirschenhauser K. 2008. Isolation and characterization of

611 microsatellite marker loci in the greylag goose (Anser anser). Molecular Ecology Resources 8:1411-1413.

612 Wilson GA, Rannala B. 2003. Bayesian inference of recent migration rates using multilocus genotypes. Genetics $613 \quad 163: 1177-1191$.

614 Winker K, Graves GR. 2008. Genetic structure of breeding and wintering populations of Swainson's Warbler. 615 Wilson Journal of Ornithology 120:433-445.

616

617 
618

619

620

621

622

623

624

625

626

627

628

629

630

631

632

633

634

635

636

637

638

639

640

641

642

643

644

645

646

647

648

649

650

651

652

653

654

655

656

657

658

\section{Supplemental Information}

Appendix 1 - List of samples used in this study, with ID, population, sample provenance, collecting date, haplotype assignment and whether the sample was genotyped with microsatellites (STRs).

Appendix 2 - Table of mtDNA haplotypes found in Anser anser individuals.

Appendix 3 - Summary of genetic variation at 14 microsatellite loci in sampled populations. Na $=$ No. of different alleles; $\mathrm{Ne}=$ No. of effective alleles. $\mathrm{Ho}=$ observed heterozygosity; $\mathrm{He}=$ expected heterozygosity; F = fixation index; HWE = Hardy-Weinberg equilibrium.

Appendix 4 - Distributions of pairwise differences (mismatch distribution) among mtDNA haplotypes for overall dataset and each sampled areas.

\section{Figure Captions}

Figure 1 - Main Anser anser flyways from breeding (red) to wintering (blue) areas (modified from IUCN, 2015). Pie charts indicate the proportion of different haplotypes (mtDNA) found in each sampled population. Colours are identical to those used in the haplotype network (Fig. 2), and haplotypes found in one area alone are the same colour.

Figure 2 - Left: median-joining haplotype network. Areas of circles represent different sampled mtDNA haplotypes in proportion to their frequencies. Distances between haplotypes are proportional to the number of base differences. Colours match those utilized in Fig. 1, and haplotypes found in one area alone are the same colour. Right: Neighbour-joining tree based on 288 bp of CR1. Sampled areas are labelled with abbreviations: NF, northern France (Oise and Nord); SWF, south-western France (Gironde, Charente Maritime and Landes); NOR, Norway; NETH, Netherlands. Numbers below branches indicate bootstrap values; only values above $70 \%$ are shown, most of the clades are supported by low bootstrap values.

Figure 3 - Factorial Correspondence Analysis (FCA) of microsatellites data. Outliers concern individuals from Nord (4 ind.), Oise, Gironde and Finnmark (1 ind.) populations.

Figure 4 - Estimated population structure in Greylag Goose sampled populations. Each vertical line represents one individual and each colour represents a single cluster. 
Figure 1 (on next page)

Map of Anser in Europe

Figure 1 - Main Anser anser flyways from breeding (red) to wintering (blue) areas (modified from IUCN, 2015). Pie charts indicate the proportion of different haplotypes (mtDNA) found in each sampled population. Colours are identical to those used in the haplotype network (Fig. 2), and haplotypes found in one area alone are the same colour. 
PeerJ Reviewing Manuscript

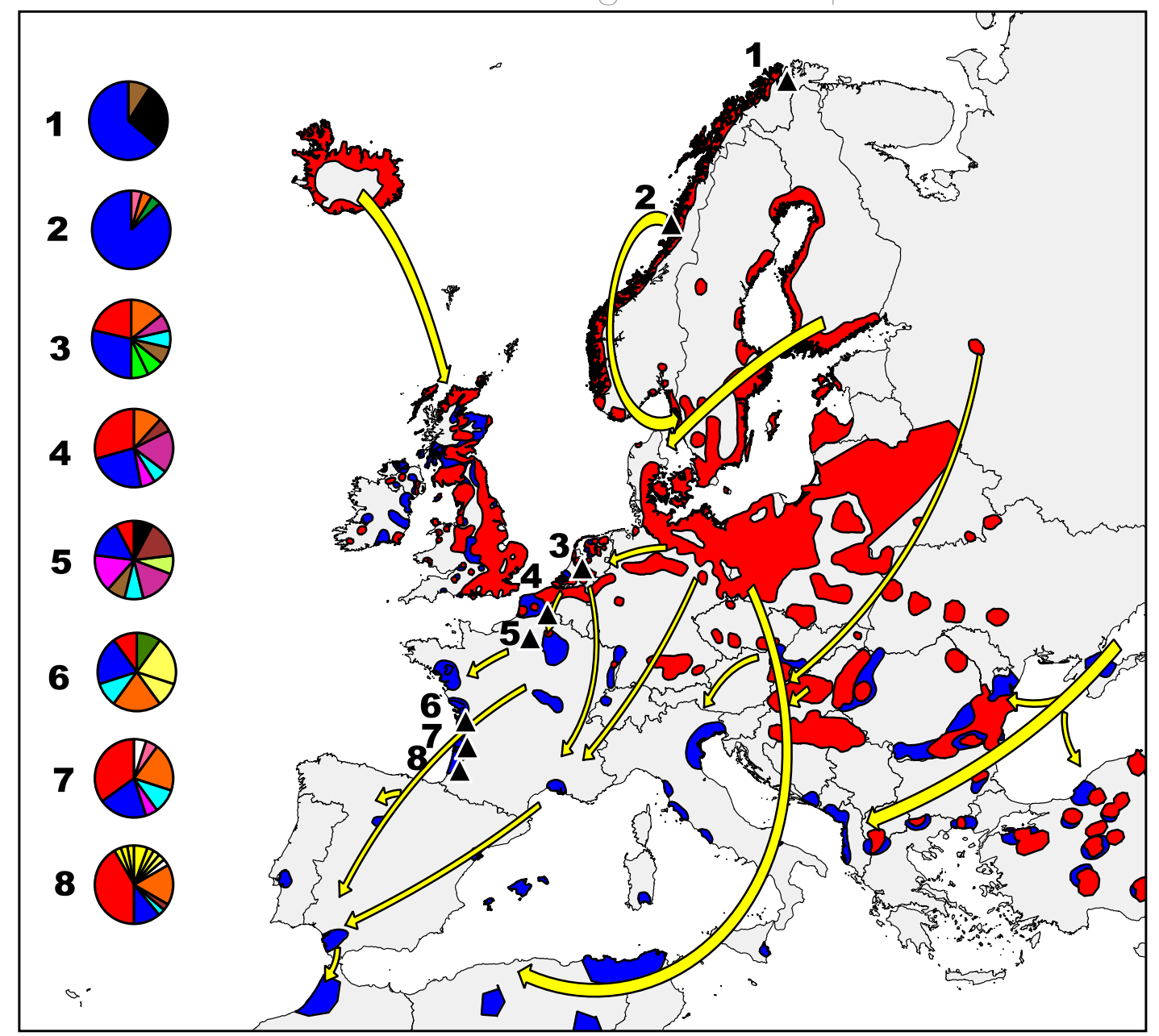




\section{2}

Image of network

Figure 2 - Left: median-joining haplotype network. Areas of circles represent different sampled mtDNA haplotypes in proportion to their frequencies. Distances between haplotypes are proportional to the number of base differences. Colours match those utilized in Fig. 1, and haplotypes found in one area alone are the same colour. Right: Neighbour-joining tree based on 280 bp of CR1. Sampled areas are labelled with abbreviations: NF, Northern France (Oise and Nord); SWF, South-Western France (Gironde, Charente Maritime and Landes); Nor, Norway; Neth, Netherlands. Numbers below branches indicate bootstrap values; only values above $50 \%$ are shown, most of the clades are supported by low bootstrap values.

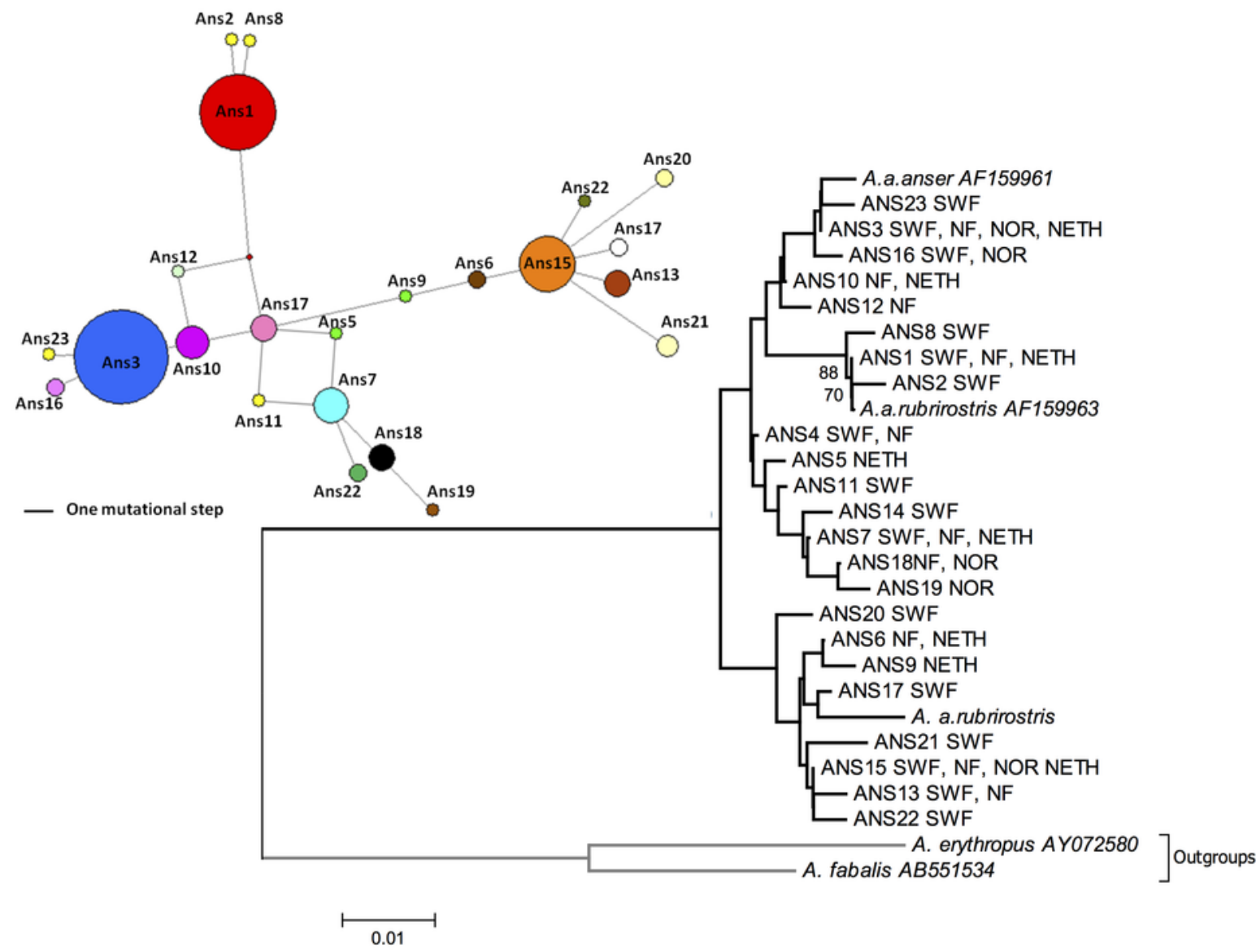


Figure 3 (on next page)

Graph of FCA

Figure 3 - Factorial Correspondence Analysis (FCA) of microsatellites data. Outliers concern individuals from Nord ( 4 ind.), Oise, Gironde and Finnmark ( 1 ind.) populations. 


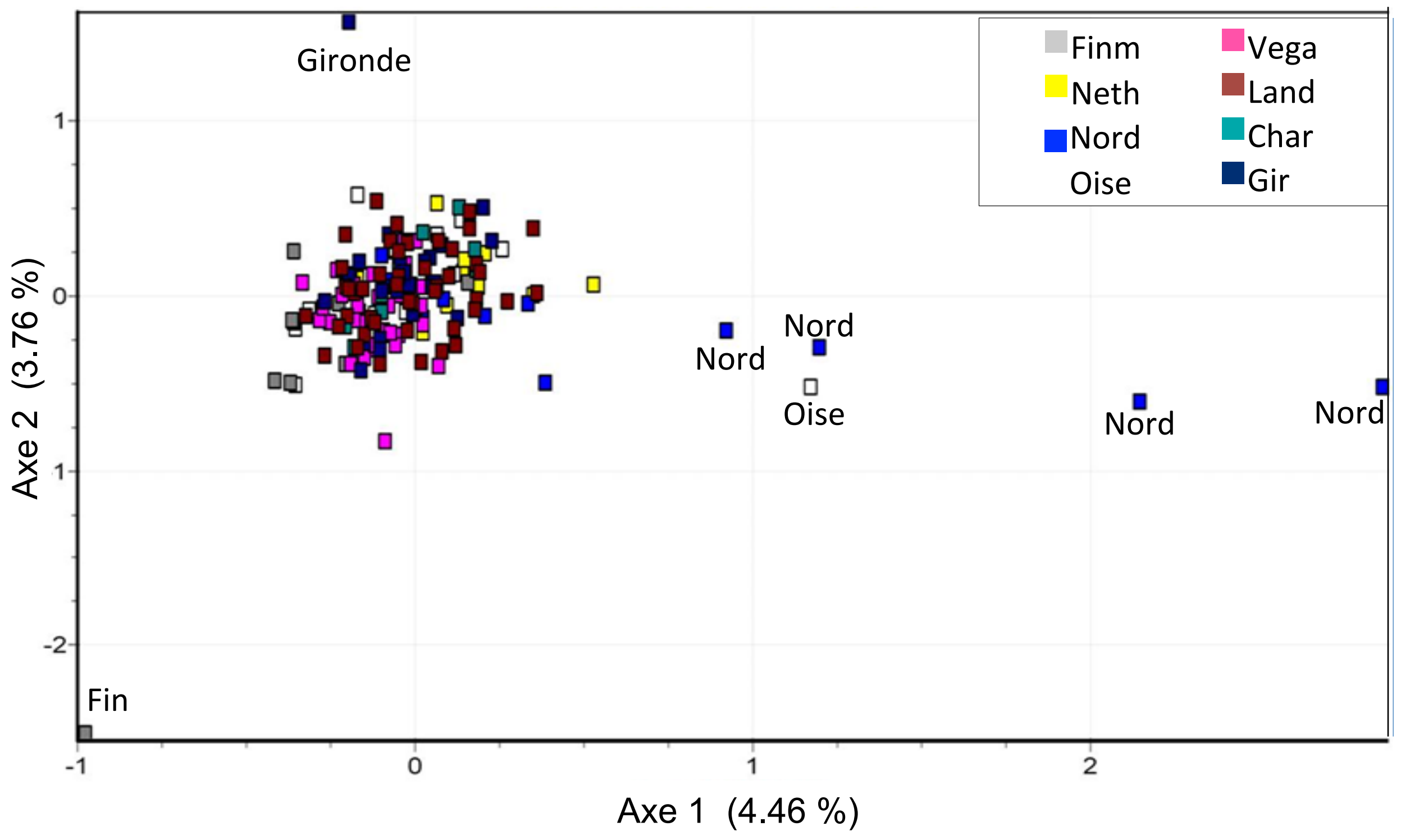


Figure 4 (on next page)

Graph of Structure

Figure 4 - Estimated population structure in Greylag Goose sampled populations. Each vertical line represents one individual and each colour represents a single cluster 

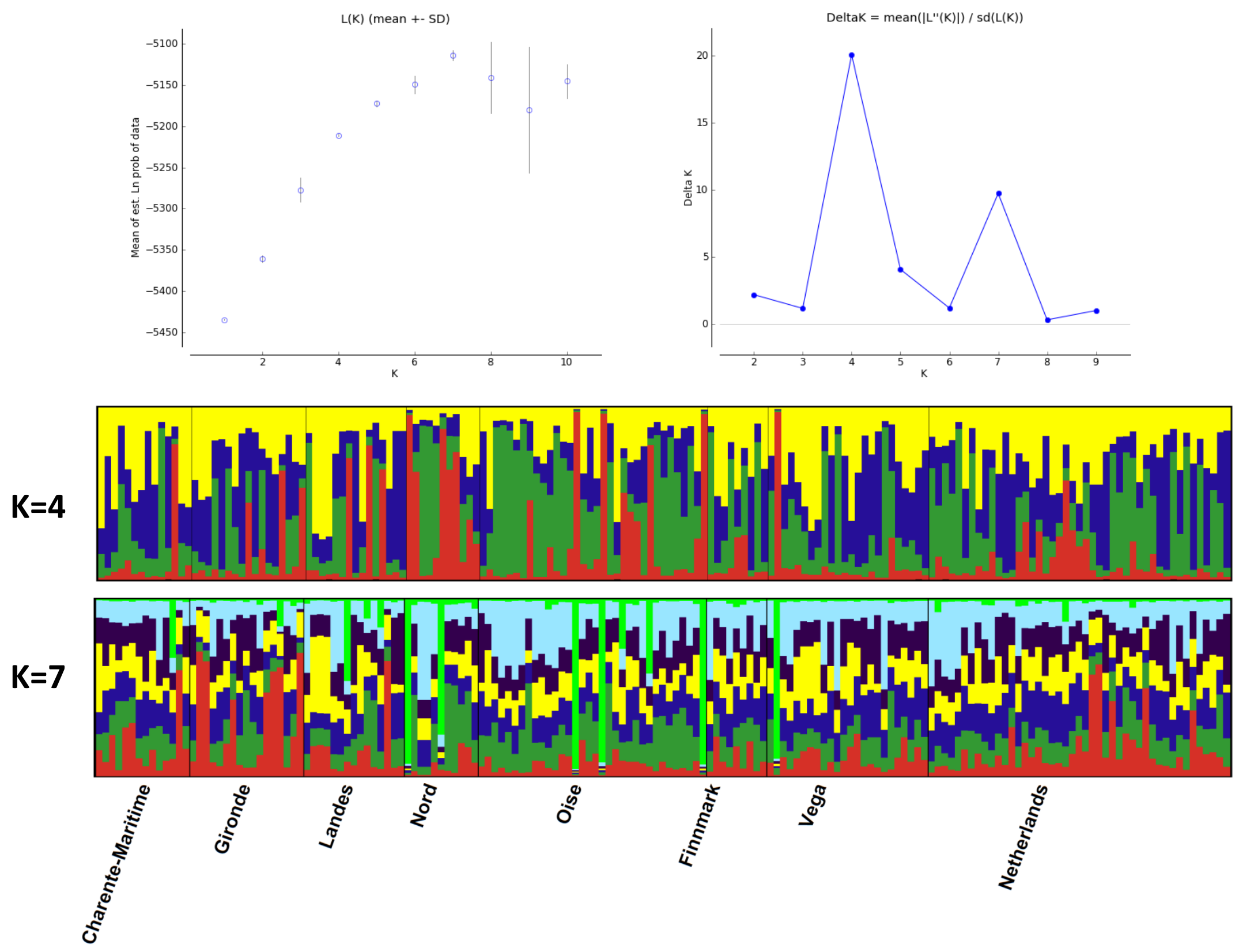


\section{Table $\mathbf{1}$ (on next page)}

Table 1

Table 1 - Genetic variability of mtDNA CR1 D-Loop. $h=$ haplotype diversity, $\pi=$ nucleotide diversity, D = Tajima's D, FS = Fu's FS. Standard errors are showed in brackets 


\begin{tabular}{|c|c|c|c|c|c|c|c|c|c|c|c|}
\hline & Population & Season & $\mathrm{N}$ & $\begin{array}{l}\text { Polymorphic } \\
\text { sites }\end{array}$ & Hapl. & $\begin{array}{c}\text { Private } \\
\text { hapl. }\end{array}$ & $h$ & $\pi$ & $\mathrm{K}$ & $\mathrm{D}$ & FS \\
\hline \multirow{3}{*}{$\begin{array}{c}\text { South- } \\
\text { western } \\
\text { France }\end{array}$} & $\begin{array}{l}\text { Charente- } \\
\text { Maritime }\end{array}$ & $\begin{array}{l}\text { Autumn- } \\
\text { winter }\end{array}$ & 10 & 16 & 7 & 1 & $\begin{array}{c}0.933 \\
(0.06)\end{array}$ & $\begin{array}{c}0.01790 \\
(0.00254)\end{array}$ & 5.156 & -0.409 & -0.664 \\
\hline & Gironde & $\begin{array}{l}\text { Autumn- } \\
\text { winter }\end{array}$ & 20 & 12 & 7 & 0 & $\begin{array}{l}0.821 \\
(0.06)\end{array}$ & $\begin{array}{l}0.01519 \\
(0.0012)\end{array}$ & 4.374 & 1.052 & 1.190 \\
\hline & Landes & $\begin{array}{c}\text { Autumn- } \\
\text { winter }\end{array}$ & 36 & 19 & 13 & 4 & $\begin{array}{r}0.798 \\
(0.06) \\
\end{array}$ & $\begin{array}{c}0.0161 \\
(0.0013) \\
\end{array}$ & 4.633 & 0.0376 & -0.360 \\
\hline \multirow{2}{*}{$\begin{array}{l}\text { North- } \\
\text { France }\end{array}$} & Nord & $\begin{array}{l}\text { Autumn- } \\
\text { winter }\end{array}$ & 17 & 10 & 7 & 0 & $\begin{array}{c}0.833 \\
(0.06)\end{array}$ & $\begin{array}{c}0.01054 \\
(0.0016)\end{array}$ & 3.025 & 0.014 & 0.433 \\
\hline & Oise & $\begin{array}{c}\text { Autumn- } \\
\text { winter }\end{array}$ & 13 & 12 & 9 & 1 & $\begin{array}{c}0.949 \\
(0.042) \\
\end{array}$ & $\begin{array}{c}0.01309 \\
(0.0020) \\
\end{array}$ & 3.769 & -0.103 & $-2.691 *$ \\
\hline \multirow{3}{*}{$\begin{array}{c}\text { Northern } \\
\text { Europe }\end{array}$} & $\begin{array}{c}\text { Norway } \\
\text { Finnmark }\end{array}$ & $\begin{array}{c}\text { Late } \\
\text { spring }\end{array}$ & 11 & 6 & 3 & 1 & $\begin{array}{l}0.564 \\
(0.13)\end{array}$ & $\begin{array}{c}0.00947 \\
(0.002)\end{array}$ & 2.727 & 1.31175 & 3.038 \\
\hline & $\begin{array}{c}\text { Norway } \\
\text { Vega }\end{array}$ & $\begin{array}{l}\text { Late } \\
\text { spring }\end{array}$ & 23 & 7 & 3 & 0 & $\begin{array}{l}0.170 \\
(0.10)\end{array}$ & $\begin{array}{c}0.0021 \\
(0.0016)\end{array}$ & 0.609 & $-2.147 *$ & 0,270 \\
\hline & Netherlands & Autumn & 14 & 11 & 8 & 2 & $\begin{array}{c}0.890 \\
(0.006)\end{array}$ & $\begin{array}{c}0.01244 \\
(0.0013)\end{array}$ & 3.571 & 0.541 & -1.112 \\
\hline $\begin{array}{c}\text { All } \\
\text { Samples }\end{array}$ & & & 144 & 20 & 23 & - & $\begin{array}{c}0.823 \\
(0.022)\end{array}$ & $\begin{array}{c}0.01331 \\
(0.0006)\end{array}$ & 3.819 & -1.419 & $-4.515^{*}$ \\
\hline
\end{tabular}

2

3 


\section{Table 2 (on next page)}

Table 2

Table 2 - Tamura Nei genetic distance assessed by mtDNA. 


\begin{tabular}{|c|c|c|c|c|c|c|c|c|}
\hline & 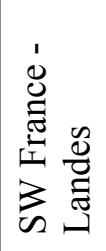 & 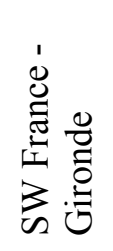 & $\begin{array}{l}\circlearrowright \\
\text { 矛 } \\
\text { Z } \\
\text { Z Z }\end{array}$ & 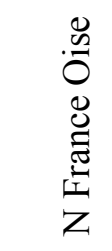 & 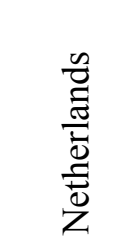 & 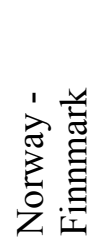 & 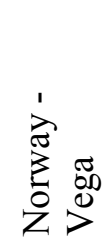 & 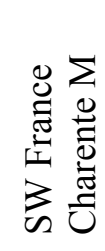 \\
\hline SW France - Landes & & 0.004 & 0.004 & 0.004 & 0.004 & 0.005 & 0.006 & 0.005 \\
\hline SW France - Gironde & 0.016 & & 0.004 & 0.004 & 0.004 & 0.004 & 0.005 & 0.005 \\
\hline N France - Nord & 0.015 & 0.014 & & 0.004 & 0.004 & 0.004 & 0.004 & 0.005 \\
\hline N France Oise & 0.016 & 0.015 & 0.013 & & 0.004 & 0.004 & 0.004 & 0.005 \\
\hline Netherlands & 0.015 & 0.014 & 0.013 & 0.013 & & 0.004 & 0.004 & 0.005 \\
\hline Norway - Finnmark & 0.018 & 0.016 & 0.014 & 0.013 & 0.014 & & 0.003 & 0.006 \\
\hline Norway - Vega & 0.017 & 0.014 & 0.012 & 0.012 & 0.012 & 0.008 & & 0.006 \\
\hline SW France Charente M & 0.020 & 0.019 & 0.019 & 0.018 & 0.018 & 0.022 & 0.019 & \\
\hline
\end{tabular}


Table 3(on next page)

Table 3

Table 3 - Summary of genetic variation at 14 microsatellite loci. $\mathrm{N}=$ number of individuals; $\mathrm{Na}=\mathrm{No}$. of different alleles; $\mathrm{Ne}=\mathrm{No}$. of effective alleles; $\mathrm{Ho}=$ observed heterozygosity; $\mathrm{He}$ $=$ expected heterozygosity. 


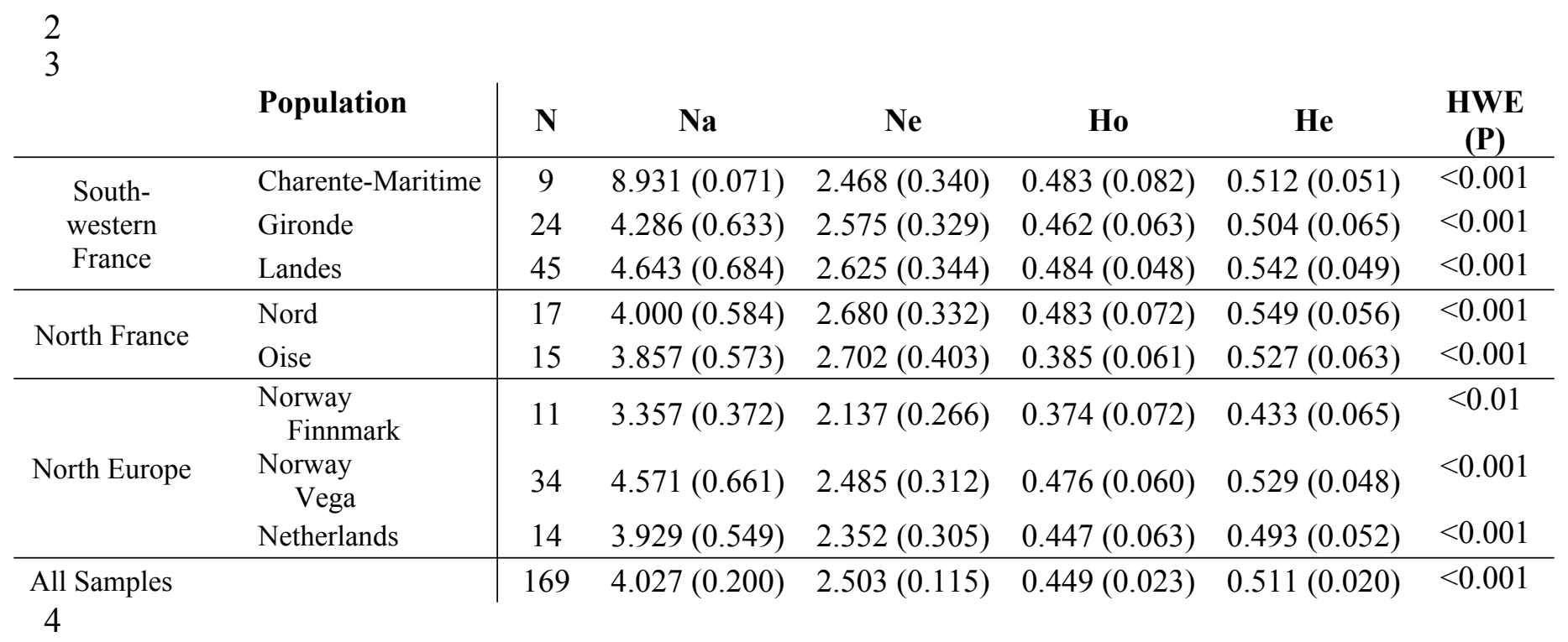




\section{Table 4 (on next page)}

Table 4

Table 4 - Mean estimated number of migrants between breeding and wintering sites as calculated with BayesAss (standard deviations in parentheses). Values on the diagonal (in bold) represent the estimated proportion of resident individuals in each population. 


\begin{tabular}{l|ccccccccc}
\hline & \multicolumn{7}{|c}{ Migration into } \\
\cline { 2 - 9 } & $\begin{array}{c}\text { Nether } \\
\text { lands }\end{array}$ & NF- Nord & NF- Oise & $\begin{array}{c}\text { NO- } \\
\text { Finnmar } \\
\mathbf{k}\end{array}$ & $\begin{array}{c}\text { NO-Vega } \\
\text { Migration from }\end{array}$ & $\begin{array}{c}\text { SWF- } \\
\text { Charente } \\
\text { Maritime }\end{array}$ & $\begin{array}{c}\text { SWF- } \\
\text { Gironde }\end{array}$ & $\begin{array}{c}\text { SWF- } \\
\text { Landes }\end{array}$ \\
\hline Netherlands & $\mathbf{0 . 8 9 0 4}$ & 0.0167 & 0.0151 & 0.0152 & 0.0160 & 0.0152 & 0.0157 & 0.0157 \\
& $(0.0338)$ & $(0.0160)$ & $(0.0147)$ & $(0.0144)$ & $(0.0154)$ & $(0.0146)$ & $(0.0151)$ & $(0.0148)$ \\
NF- Nord & 0.0145 & $\mathbf{0 . 9 0 0 9}$ & 0.0135 & 0.0140 & 0.0144 & 0.0133 & 0.0149 & 0.0145 \\
& $(0.0139)$ & $(0.0316)$ & $(0.0130)$ & $(0.0135)$ & $(0.0138)$ & $(0.0129)$ & $(0.0143)$ & $(0.0141)$ \\
NF- Oise & 0.0142 & 0.0460 & $\mathbf{0 . 6 8 2 0}$ & 0.0144 & 0.0138 & 0.0136 & 0.2023 & 0.0137 \\
& $(0.0135)$ & $(0.0238)$ & $(0.0146)$ & $(0.0139)$ & $(0.0132)$ & $(0.0132)$ & $(0.0344)$ & $(0.0133)$ \\
NO- Finnmark & 0.0191 & 0.0212 & 0.0174 & $\mathbf{0 . 8 6 1 9}$ & 0.0215 & 0.0177 & 0.0219 & 0.0194 \\
& $(0.0183)$ & $(0.0198)$ & $(0.0165)$ & $(0.0394)$ & $(0.0210)$ & $(0.0164)$ & $(0.0211)$ & $(0.0184)$ \\
NO-Vega & 0.0085 & 0.0078 & 0.0078 & 0.0081 & $\mathbf{0 . 9 4 3 9}$ & 0.0079 & 0.0081 & 0.0081 \\
SWF- Charente & $(0.0081)$ & $(0.0078)$ & $(0.0078)$ & $(0.0079)$ & $(0.0192)$ & $(0.0077)$ & $(0.0079)$ & $(0.0077)$ \\
Maritime & 0.2072 & 0.0175 & 0.0173 & 0.0176 & 0.0181 & $\mathbf{0 . 6 8 7 2}$ & 0.0177 & 0.0174 \\
SWF- Gironde & $(0.0379)$ & $(0.0167)$ & $(0.0165)$ & $(0.0166)$ & $(0.0174)$ & $(0.0192)$ & $(0.0168)$ & $(0.0166)$ \\
& 0.0114 & 0.0107 & 0.0111 & 0.0199 & 0.0109 & 0.0110 & $\mathbf{0 . 9 1 4 2}$ & 0.0109 \\
SWF- Landes & $(0.0112)$ & $(0.0105)$ & $(0.0102)$ & $(0.0160)$ & $(0.0104)$ & $(0.0107)$ & $(0.0270)$ & $(0.0105)$ \\
& 0.0069 & 0.0068 & 0.0063 & 0.0067 & 0.0065 & 0.0063 & 0.0068 & $\mathbf{0 . 9 5 3 8}$ \\
& $(0.0069)$ & $(0.0067)$ & $(0.0063)$ & $(0.0066)$ & $(0.0064)$ & $(0.0063)$ & $(0.0067)$ & $(0.0164)$ \\
\hline
\end{tabular}

3 